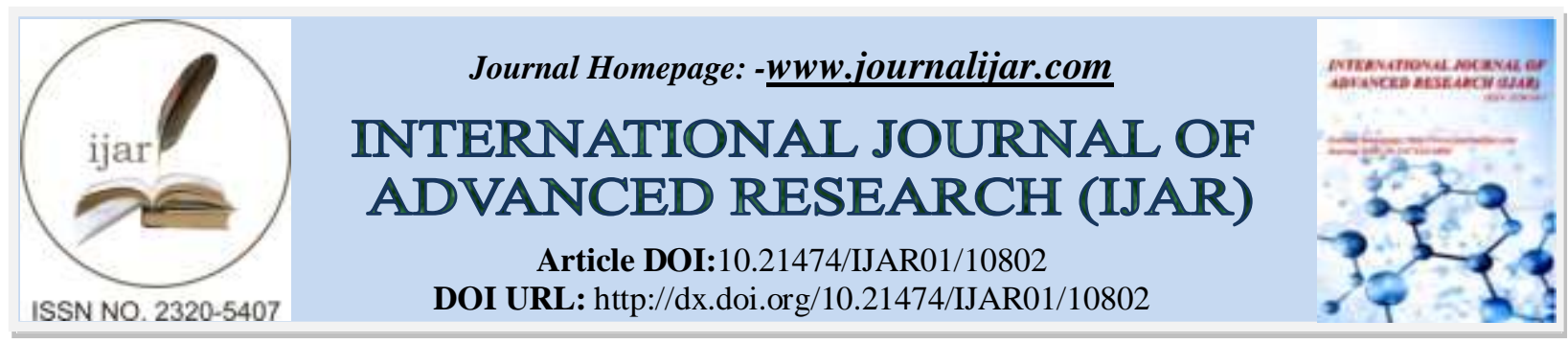

RESEARCH ARTICLE

\title{
THE EFFECTIVENESS AND EFFICIENCY OF THE LAW, THROUGH THE LEGISLATIVE EVALUATION IN MÉXICO
}

\author{
Kenya Hernandez Vinalay, María del Rocío García Sánchez and Verónica Mayren Rodríguez Herrera \\ School of Law-Acapulco of the Autonomous University of Guerrero, México.
}

\section{Manuscript Info}

Manuscript History

Received: 10 February 2020

Final Accepted: 12 March 2020

Published: April 2020

Key words:-

Legislative Evaluation, Effectiveness

And Efficiency

Abstract

Laws are rules and guidelines that aim to ensure good coexistence and establish public order. Laws must be fundamentally fair, reasonable and equitable with the aim of building an effective rule of law and, as a result, achieve social harmony, as well as adequate economic and political development. Today, laws and legislators are not fulfilling their task, since the former do not conform to social reality, while in the case of legislators, on many occasions they do not even have enough information and training to do a good job; the lack of preparation of the legislators, the ignorance of the realities and social needs, the simulation and the lack of vocation to serve and respond to the social needs of those who elected them to represent them, are the perfect combination for the divorce between the representative and their constituencies, and the real task of a political representative, which is to serve and represent the interests of citizens, pass to the background. Therefore, the evaluation of the laws is an alternative to recover the rule of law, and clean up the current regulatory system, to make it more accessible to citizens, and simplify its use to make law a useful tool for social harmony and development of the country.
\end{abstract}

Copy Right, IJAR, 2020,. All rights reserved.

\section{Introduction:-}

The evaluation exercise involves making a diagnosis, to improve, correct, debug, and contribute to better governance, achieve effective compliance with the laws, and therefore strengthen the rule of law, which in turn will promote social and economic development, generating the conditions to reach a better standard in the quality of life of citizens.

An important condition in the field of legislative theory has been brewing since a little less than a decade, that of a renewed movement for the quality of the law. The position today is that not only what the laws say is significant but what they achieve, that it is necessary to know whether the behavior of their recipients fits their perspectives or not, what are their consequences and effects, and what is the cost of achieving its goals.

While it is true that there are proposals to evaluate the performance of the functions of legislators, in this case it is proposed to create a national legislative evaluation body that offers effective evidence of its results. While the legislator is in charge of legislating and approving laws that regulate any problem, it is not subsequently verified once the law comes into effect - if the law has indeed caused the desired effects for the benefit of society. 
Dr. Luis Ponce de León Armenta, (Luis, 2010) considers the law as the most important manifestation of legal order, and classifies the legislation as follows:

1. Constituent: The one that constitutes the institutions, including the most important that is the State.

2. Constitutional: Expressed by fundamental norms of a general nature that expresses the will of the population, embodied in the Constitution and that by their generality require regulations for their application.

3. Regulatory: It is the one that develops and breaks down the constitutional legislation, to achieve its application to specific cases.

4. Fair: The one that is generated in congruence with the law as a science in its integrity, in its principles, in its contents and in its values. According to the author analyzed, the predominance of this type of legislation promotes the scope of justice and legal certainty.

5. Unfair: It is the legislation that is formalized by the legislative bodies of the States, without any consideration of the experience of the times and of the law as a science, it is generally carried out without any analysis and without previous scientific investigation of the law, in many cases it is imposed for certain interests against the general interest of the company. Causing insecurity and injustice, and other social ills.

6. Temporary: It is applied temporarily, with the function of linking the legislation that is repealed with new legislation that becomes effective. Allowing an adaptation of the new legislation to the social reality.

7. Ordinary: It is the current legislation that applies to specific cases, derived from the regulation of the constitutional legislation.

8. Written: It is the one manifested in a legislative text that can acquire the character of law, code, regulations, etc.

9. Customary or unwritten: It is the one that without expressing itself in written form, is complied with because it is in the conscience of the peoples. Since they are legal norms that are imposed externally and coeribly through mechanisms imposed by the group or political organization.

From the perspective of Dr. Ponce de León, the legislation is classified based on various characteristics, not only by its origin and form, but by its purposes, and by adding the classification of fair and unfair legislation, it also takes into account the impact social and legal that these laws generate in society, emphasizing that it is imposed by interests contrary to those of the common good, without proper analysis and without prior scientific research that supports its raison d'être, hence, that it favors the establishment of a regime of injustice.

Francisco J. Laporta, (GONZALEZ J, 2007) proposes the following classification of laws emanating from Congress:

1. Laws-to measure: that respond to individual cases, problems and situations and detract from the norm their traditional qualities of abstraction and generality.

2. Political receptiveness-laws: that meet a present and urgent objective and are instruments to generate de facto states of an economic nature, such as plans or programs to combat inflation or to foster the growth of the Gross Domestic Product.

3. Empty-laws: which are issued under the assumption that there are previously other norms or institutions that are not there, and / or that are enacted without financial resources to fulfill their purposes.

4. Virtual-laws or show-laws: which only intend to "project a message or open a debate ... are purely rhetorical laws that generate the feeling that ... public opinion aspirations are satisfied ..."

Francisco Laporta, unlike the previous classification, defines them with a more political criterion, based on the political and social moments in which they are generated by the Congress, this classification is also quite accurate, if one takes into account that indeed, many laws born on the occasion of an electoral aspiration, leaving in clear evidence that the legislation is used most of the time as a political spectacle, regardless of its true objective and leaving in oblivion the great commitment that implies generating legislation with based on real needs, prior to an analysis and scientific research that ensures its quality.

Laws must be created with the main purpose of attending to the common good, responding to the needs that arise according to the circumstances and phenomena that are experienced in a society in constant change. It is clear that the laws must go through a process of analysis and evaluation once they are in force. Therefore, in order to achieve the constitutional and general principles of law, we consider that the evaluation methods must be carried out by institutions of great moral solvency, without links with the with the political organizations, and rather go to the scientists, who through their analysis and scientific products can give us the guideline to recover the good progress of the State. 
Effectiveness and efficiency are fundamental aspects to determine if a law is meeting its objectives. On the other hand, the evaluation would not make sense, if it were not a tool to improve the quality of what is going to be evaluated, therefore it is essential that such evaluation is aimed at proposing:

1. The improvement, or repeal of a law if necessary.

2. That during the evaluation, the social, economic and legal impacts that the laws have produced since their validity and application can be determined

Applied to legislation, we understand that when verifying the effectiveness of a law, it will analyzing if it meets the objectives that were set in its creation. Each law includes a statement of motives that explains the reasons for its inclusion in the systemnormative, therefore it is important to monitor it, to verify if this was achieved or it is necessary to make modifications or substantial changes to also give it thefollow-up to the problem that gave rise to that law.Additionally, when applied to the law, the efficiency criterion refers to mainly, verify if it has the resources, materials, and human resources to achieve the effects they seek, based on the provisions of the legislator, that it may used effectively in reality, with the rational use of resources.

Democracy, harmony and social development depend on legislative policy, which are determined through the legal order that will regulate all areas of social life through the laws that the legislative assembly approves and issues; However, at present we have a very complicated, excessive, sometimes redundant and contradictory legal framework in others, which favors legal uncertainty, which in many cases makes it difficult to access prompt and simple justice for citizens. Just to give an example, on the website of the Chamber of Deputies, in the section of current federal laws, updated to November 8, 2019; there are a total of 301 laws, in the current federal laws regulations section, updated as of October 17, 2019 there are a total of 133, and in the regulations, statutes, manuals and other regulatory standards section published in the official gazette of the federation as of 2002, updated as of November 11, 2019, a total of 639 applicable only at the federal level; not counting laws and regulations at the state and municipal level. As a result of this problem, the present research work has the purpose of proposing an addition to Title Third bis of the Political Constitution of the United Mexican States, to raise the obligation to evaluate the quality and efficiency of laws to constitutional status, this, through the creation of an autonomous constitutional body called the National Commission for Legislative Evaluation, which would be based on article 107 bis.

For this reason, it is of great importance to create an organism that take charge of this task, of verifying and evaluating the laws created by the legislative assembly, if they are efficient, and are fulfilling the purposes for which they were conceived. This evaluation it would be specified to analyze the effects after its validity, that is, the call ex post evaluation or retrospective evaluation, and through this process know the effects that had to determine its permanence, modification or abrogation.

The idea of evaluating the laws is not new, Montesquieu himself, in his work the spirit of the laws, foresaw it:

"The representative body should not be elected to make active resolutions, in which it would not demonstrate success, but to make laws or examine whether they have complied with this: this enters fully into the sphere of their aptitudes and no one but they can do it good". (MONTESQUIEU, 1986)

One of the factors that makes the legislative evaluation necessary is that the congresses pass several laws in relatively short periods of time, without taking into account what the social, economic or legal impacts will be, after the law has entered into force, since no There is a follow-up to know if these laws impacted effectively on their recipients, or if the problem that led to the creation of those laws has been resolved, that is, not only what the laws express is significant but what they achieve.

\section{Justification:}

The Political Constitution of the United Mexican States, is the fundamental instrument, not only for the legislative function, but for the entire legal life of our country, any legal figure or institution, must seek its genesis in our maximum legal order; In this way, the legislative function finds its foundation in constitutional norms, since its structure, operation and limits are found in this fundamental norm.

The Congress has its foundation for their organization and operation in secondary laws, and internal regulations, which must be subject to the Supreme Law. 
Indeed, in the Third Title, Chapter II, of the Political Constitution of the United Mexican States, we find articles 50 to 79, which provide the fundamental basis for the regulation on the organization and operation of the Congress of the Union.

For Mario de la Cueva (Mario, 2014), the Constitution can be defined as:

"... The formal source of law, and indeed the only one that has the character of primary source placed above the State, because it contains the essence of the political and legal order, therefore, the source from which all the norms of the conduct of men and those that determine the structure and activity of the State..."

For its part, the Dictionary of the Royal Academy of Language (Lengua, 2019) considers it as:

"Fundamental Law of a State, which defines the basic regime of the rights and freedoms of citizens and the powers and institutions of their political organization"

The Federal Political Constitution is the Supreme Law, through which, the bases and the form of Government are established, as well as the division of powers and functions of each of these, among which are, the Legislative Power, and its operation.

It is in the Basic Law, where the basic aspects of the legislative action are established in a generic way, being in charge of the secondary systems, the total and specific regulation that regulates the legislative function. We have so that the stages of the legislative process are:

1. Initiative: is the right to propose a body of precepts or regulatory provisions. Constitutional Article 71, it is foreseen, who can make use of this right.

2. Discussion: the Chambers of Congress determine, through the corresponding mechanisms, whether or not they should approve the initiatives presented.

3. Approval: it is the act, by means of which, the chambers, determine to approve the initiatives of law, proposals to their consideration.

4. Sanction: once an initiative is approved, it must be sent to the Executive Power for acceptance.

5. Promulgation: is the formal recognition made by the Executive regarding the law that has been approved according to law and must be obeyed.

6. Publication: understood as the act, through which a law is disclosed to those who must comply with it, and which is usually carried out through the Official Gazette of the Federation.

To achieve the efficiency and effectiveness of a law, we consider that this legislative process must be subject to a legislative technique and rationality levels that allow the quality of the law and the creation of an evaluation body that determines the social, legal and economic impact of the norms in Mexican society.

Starting from that point, for Manuel Atienza, there are five levels of rationality that should be taken into account in the process of creating the standards, which quoted by Efrén Chávez Hernández, (CHÁVEZ Hernández, 2016) points out:

“...Manuel Atienza speaks of five models, ideas or levels of rationality, from which one can contemplate legislation that is: linguistic, legal-formal; pragmatics; teleological and ethical..."

Manuel Atienza, part of considering the process of creating norms (legislation) as a series of interactions, in which diverse elements are involved: edictores (the authors of the norms), recipients (those to whom the norms are directed), legal system (set of which the new law becomes part), ends (objectives or goals that are pursued when establishing the laws) and values (ideas that serve to justify the ends); and the product of such interactions are the laws.

Regarding the rationality levels proposed by Manuel Atienza, Gonzalo Santiago, the following stand out:

"Manuel Atienza is the one who has best exposed the importance of reason in the process of creating legal norms, since he considers that jurisdictional rationality becomes unattainable without prior legislative rationality, since legislative rationality - or, at least, true degree of legislative rationality - it is a necessary budget to be able to talk about rationality in the application of the Law " (Gonzalo. 2006)

Derived from the above, we can understand each of these types of rationality as follows: 
Linguistics.- It is that the sender must be able to transmit a message fluently to the receiver. It is clarity in language, so that the norm is understood.

In fact, if a rule is not understood, it will cause problems when applying it, both for citizens, as well as for the authorities themselves, hence its text should be as clear as possible and understandable, since it should not be forgotten that the laws are going aimed at society, and in many cases, there are social groups that do not have a degree of instruction, which allows them to understand concepts, terms and definitions provided by law.

Regarding this level of rationality, we can find a brief mention, in the regulations for the Internal Government of the General Congress of the United Mexican States, in article 165, referring to the formula for the issuance of laws.

"Article 165.- The laws shall be drafted with precision and clarity in the manner that they had been approved, and upon issuance they shall be authorized by the signatures of the Presidents of both Chambers and of a Secretary of each of them, if the law had been voted by both. "(Union. 2019)

Legal-formal. The new law must be harmoniously inserted into the current legal system.

Thus, if a law that is going to enter the new legal system is contrary to an existing one, only chaos and confusion will be created when applying it.

Pragmatic. It is the real possibility that what is stated in the law can be carried out. It refers to their being feasible to guarantee their materialization in reality.

At this point, the following reflection should be carried out. All the postulates of a law should be as closely attached to the reality of things; an unreal law, alone is doomed to failure, since it can never be put into practice, and it will only be a dead letter.

Teleological. It is related to the purposes pursued by the norm, an end that society must consider valuable and necessary.

All legal norms must be aimed at creating or preserving a valuable purpose for citizenship, only then can their existence be understood.

Ethics. Refers to the values included in the new norm. Indeed, in this aspect, legal norms must preserve a fundamental value, such as freedom. Security, life, health, among others, in such a way that, directly or indirectly, these legal norms, protect these values, as an integral and necessary part of society.

Although, the law should not be reduced merely to rules of conduct imposed in the exercise of the power of the State, but rather precepts imbued with justice, wisdom, sanity, logic, intelligence, reason and prudence, appropriate to nature human and, although, according to the idiosyncrasy of the people to which they are destined, encouraged by the purpose of removing the vices that harm them.

The researcher Jorge Fernández Ruiz, mentions that the legislative technique must be oriented towards improving the quality of the laws. "Within the science of legislation, which deals with the elaboration, suppression or modification of legal norms, the legislative technique that overlaps with parliamentary law becomes particularly important, and oriented with the purpose of improving the quality of laws, by saying of the Spanish professor Fernando Sainz Moreno, is: the activity aimed at building a legal system well structured in its principles and integrated by correctly formulated norms"

The same author, rightly recognizes, that in our country, the studies of legislative technique are very few, and the lack of technique or specialization in the process of regulatory creation, favors improvisation and all the problems that have brought with it in the last decade the different laws that have been enacted. "In Mexico, studies of legislative technique have been relegated by virtue of which little has been researched and written on the subject, which has led to improvisation in the elaboration and drafting of laws, as well as a precarious bibliography on the subject. In the best case, references on the subject are part of the content of Constitutional Law, so it is analyzed in a very general way, without going into the details of the multiple facets that make the legislative process an important chapter of Parliamentary Law"(MEEHAN, 2019) 
It is clear that rationality in its various modalities must be present before and during the process of legislative creation, since in this way that rationality can be reflected in its application and therefore the rule will meet the needs that gave rise to it.

If a legal norm is not evaluated, there is a risk of incurring a practice harmful to society, where the production of laws is large, but the effectiveness is low.

\section{And the role of the legislator?}

While it is true, that one of the functions of legislators, is precisely to carry out the demands of society to Congress, no less certain is that, this function today, by lawmakers is almost nil.

First, it should be noted that, within the Congress, there are a number of problems, such as accountability, or that the legislators themselves do not even have enough information to do a good job, that is, they are not informed, as is the case with federal programs.

The fact that a legislator does not even know what programs exist, leaves much to be desired in his actions, since it is as if a surgeon did not know all the parts of the human body. To a legislator while his salary is covered, he can hardly think about the needs and demands of society, much less specialize in his work, take courses, prepare better at the time of being legislators.

In effect, a legislator must be prepared for the performance of his assignment, however, many of the current legislators do not reach their positions, because of their intellectual trajectory, but rather, because of the political function they have performed.

This situation, propitiates the lack of commitment of the legislators, since as it has been mentioned, they do not carry out their work to favor a sector of the society, but to a certain political group. Obviously, if there is no real commitment from legislators, then you definitely cannot have good laws.

It is public knowledge that many law initiatives are debated in a simulation environment, since these were previously agreed between the different power groups, so they are only presented to give formality to the legislative process.

With the same perspective, Jon Elster (GARGARELLA, 2014), states the following about the discussions held in secret:

"They tend to favor the negotiation mechanisms and the explicit recognition of self-interest", so, as a result, the arguments on which they finely coincide tend to reflect the negotiating power [of each agent] and not the force[of the arguments presented]. Thus, the fact that the body of representatives is relatively small, that its members are bound by similar interests and ambitions, that they spend a lot of time in mutual contact (developing "internal solidarity")

Definitely democracy, together with legality and legitimacy, is the channel that can take society to the true rule of law; and with that, to a harmony among the community, but it is clear that for this, adequate and correct regulations must be legislated and to reinforce this fundamental function of any democratic State, the ideal would be to periodically evaluate the effects and effectiveness of that task legislative.

In order to achieve a social harmony, it is essential to build a culture of legality, which manifests socially with respect the rights of each and every one of the members of the community, as well as in compliance with the obligations to each correspond.

Unfortunately, at present, the figure of the legislator before society, is fragmented, most believe that it is only a political class that is interested in their own benefits and their party, leaving aside the true demands of society, which is reflected in their norms that they create, which in many cases do not respond to people's expectations.

\section{Literature Review:-}

In democratic countries governed by the principle of division of powers, the formation of laws governing the operation of the State is in charge of legislative power, acting under the parameters of its own domestic legislation. 
It is through this process of formation of the law by which political decisions become law. Therefore, it is essential to know the legal framework that regulates this important process, its formalities and implications.

In Mexico there is no history of any legislative evaluation body that can guarantee that a law is fulfilling its mission and give security to society, therefore, the importance of evaluating and reassessing legal norms, after its entry into force.

We carried out a review of the literature and we could realize that in Mexico the post legislative stage is the most important, because it is here that the effects of the laws are analyzed, it is evaluated, if indeed a legal norm is complying with the explanatory statement that support it, in other words, with its teleology.

The work of a legislator should not be left alone in the publication of a law; His role goes further, he must analyze whether his work is reaching society, if he is solving the problems he intended when he proposed his initiative, and if he was not fulfilling it to some extent, make the necessary modifications.

The evaluation of a law is mandatory for the legislator in the pre-legislative and legislative stage, because in a rule of law, only laws can grant security to people, so that if a law is not fulfilling its mission, therefore, society is not being receiving security, therefore, the importance of evaluating and reassessing legal norms, after its entry into force.

The above is very true, since a legislator is an expert in politics, but not in law; This situation favors that the legislators at the time of carrying out their task do not even have an idea of what they should do; which to a certain extent is understandable, since all his life he has only spent political campaigns, without the minimum desire to specialize in legislative matters, rather the only interest they reflect when occupying a seat in the congress, is to remain effective in the public eye, to negotiate in your party, the next public office.

\section{Research questions:}

Should Mexican laws be evaluated once published to determine their effectiveness?

\section{Materials and Methods:-}

This work was carried out under an intuitive method that allowed us to analyze the problem about the effectiveness of laws once they come into force and have application in society. The dialectical method allowed the confrontation of own ideas with other authors on the subject that was investigated and it was through the historical method that I can investigate if in other mementos of the legislative history of Mexico there have been legislative evaluation bodies that allowed to measure the effectiveness of the laws. The inductive-deductive method was also used in which a documentary review of the legal framework of the federal legislative power was made, as well as a bibliography on the legislative process, which allowed for gradual and progressive reasoning to be able to describe, analyze, explain and conclude through the deduction on the importance of the creation of a national evaluation body whose function is to measure the effectiveness of the laws once they have entered into force.

\section{Results and Discussion:-}

We can say that normative ineffectiveness generates various problems, which derive from the lack of order and conditions that generate well-being and resolve social demands on the part of the State, with this loss of legitimacy, society loses direction, and confidence in institutions, creating a chaotic panorama, where society retreats defensively, every time the State makes an important decision, and the State-Society relationship is almost antagonistic.

The law is an important element to achieve social balance and respect for the rights of people. Since only through this can the actions of the company be regulated, and in its case establish penalties for those who do not adapt their actions to the corresponding regulations; it must seek the basic needs of the community, it must respond to people's expectations, and it must largely solve their problems, because otherwise, the effectiveness of a law may be considered null. 
The primary function of the Law is the solution of social problems, the regulation of the protection of the minimum rights of man; Based on the above, the existence of the law can be understood, if it is not capable of it, then there is no reason for its existence.

In this context, fair and reasonable laws cannot be expected to exist when:

The legal framework of the legislative assembly, that is, the Regulation for the Interior Government of the General

Congress of the United Mexican States, must gather aspects related to legislative technique.

Legislators must be trained to carry out their task with technique or specialization in the process of creating regulations.

Consequently, if a law does not demonstrate a true solution, directly or indirectly, to one of the multiple problems of society, then said law is not fulfilling its main objective, which is to solve problems of the community. Undoubtedly, the good course of society is what should guide the purpose of a law, and if said law solves the problems of the community, then we can say that said law is fulfilling its function.

\section{Conclusions:-}

A legislator must ensure the security of the community, as it must be a representative of society, and must bring to the Congress the expectations of the community to debate. The important thing is not to create many laws, but rather to create regulatory bodies of high quality and content, that favor the development of society, that seek social harmony, as well as justice and security, basic principles that must contain all the norms to build an authentic rule of law.

It is evident that when it is possible to combine a rule of law in its two senses, society can assume full confidence in legality, justice and security, thus forming a social harmony between society and the State, where citizens will abide by laws, because he knows that it is the only way to guarantee the correct development of his country, however, this does not seem to happen in Mexico, the problems that plague us are diverse, and society seems to have lost its way, discomfort is widespread between different social sectors.

In order for a legal rule to have an impact, it must be well directed to address and solve a specific aspect. Thus, there are laws that have not been well directed since its inception, which, of course, cannot produce the impact that might have been expected from them. Therefore, it is necessary to propose the evaluation, as an effective method to improve the quality of the legislation that governs us, and in this way purify, perfect, clean up the regulatory system to make it more accessible, feasible and thereby contribute to strengthening the Rule of law.

Evaluation is an indispensable mechanism to increase the quality of legislation in Mexico, and to strengthen the rule of law. Direct the evaluation through the criteria of effectiveness and efficiency, with an analysis based on the principles of the right of fundamental character in a norm, which are legal security and justice. Legislative effectiveness is measured through the achievements and goals that a law hasobtained, as well as with the fulfillment of its objectives. While efficiency, is responsible for verifying that there are human and material resources, and that these are used in an optimal and functional way, to give effectiveness to the norm.

It is necessary then, the creation of a National Evaluation Council Legislative. Through the addition of Title Third bis in the Political Constitution of the United Mexican States, to elevate to constitutional rank the State's obligation to evaluate the laws, and from this constitutional mandate, the creation of a constitutional body autonomous in charge of $\mathrm{t}$ this task, since to achieve true conditions of governance, well-being, security and national development, it is necessary strengthen the rule of law, since the laws are the ones that support all the public policy in the various areas of national life.

\section{References:-}

1. CHÁVEZ Hernández, E. (2016). El Derecho Parlamentario estatal mexicano, análisis y propuesta de reforma. México: UNAM.

2. GARGARELlA, R. (2014). Crisis de la representación política. México: Fontamara.

3. GONZALEZ J, S. (18 de Dciembre de 2007). Proliferación legislativa. Periódico Crónica, págs. 7 -8. 
4. Gonzalo., S. C. (2006). Racionalidad y argumentación jurídica legislativa. México: Cámara de DiputadosCentro de Estudios de Derecho e Investigaciones Parlamentarias.

5. Lengua, R. A. (12 de Julio de 2019). Diccionario de la Real Academia de la Lengua. Obtenido de https://dle.rae.es/constituci\%C3\%B3n?m=30_2

6. Luis, P. d. (2010). Modelo Transuniversal del Derecho y del Estado. México: Porrúa.

7. Mario, D. L. (2014). Teoria de la Constitución . México: Porrúa.

8. MEEHAN, J. H. (22 de Septiembre de 2019). Diccionario Universal de Términos Parlamentarios . Obtenido de http://www.diputados.gob.mx/sedia/biblio/virtual/dip/dicc_tparla/t.pdf

9. MONTESQUIEU, C. L. (1986). El espíritu de las leyes Tomo I. Madrid: Librería General de Victoriano Suarez.

10. Unión., C. d. (18 de Septiembre de 2019). Cámara de Diputados. Obtenido de http://www.diputados.gob.mx/LeyesBiblio/pdf/219.pdf. 